\title{
PENGARUH KETERAMPILAN DIGITAL ABAD 21 PADA PENDIDIKAN KEWIRAUSAHAAN UNTUK MENINGKATKAN KOMPETENSI KEWIRAUSAHAAN PESERTA DIDIK SMK
}

\author{
Dede Rusmana, Universitas Sebelas Maret Surakarta \\ dederusmana555@gmail.com \\ Wiedy Murtini, Universitas Sebelas Maret Surakarta \\ wiedymurtini@staff.uns.ac.id \\ Harini, Universitas Sebelas Maret Surakarta \\ harini_uns@yahoo.com
}

\begin{abstract}
ABSTRAK
Kewirausahaan mempunyai peranan penting dalam ekonomi dan penciptaan lapangan pekerjaan. Namun, kondisi lapangan pekerjaan di Indonesia sangat kecil sehingga tingkat pengangguran masih banyak. Pengangguran terbesar berasal dari lulusan SMK. Berdasarkan observasi awal, kompetensi kewirausahaan siswa termasuk rendah. Perlu adanya pembelajaran yang menunjang dan sesuai dengan perkembangan zaman abad 21. Berdasarkan hal tersebut, perlu adanya kajian mengenai kompetensi kewirausahaan yang direlevansikan dengan pendidikan kewirausahaan dan komponen kemampuan digital abad 21. Metode pada penelitian ini menggunakan pendekatan kuantitatif. Analisis penelitian menggunakan Structural Equation Model (SEM) dengan instrumen kuesioner dan responden adalah peserta didik SMK. Hasil penelitian menunjukkan pengintegrasian keterampilan digital abad 21 pada pendidikan kewirausahaan memiliki efek yang positif dan signifikan dalam peningkatan kompetensi kewirausahaan pada peserta didik SMK.

Kata Kunci: Keterampilan Digital, Pendidikan Kewirausahaan, Kompetensi Kewirausahaan.
\end{abstract}

\section{ABSTRACT}

Entrepreneurship has an essential role in the economy and job creation. However, the conditions of employment in Indonesia are minimal so that the unemployment rate is still large. The most significant unemployment comes from SMK graduates. Based on preliminary observations, students' entrepreneurial competence is low. Learning needs to be supported and under developments in the 21st century. Based on this, there needs to be a study of entrepreneurial competencies that are relevant to entrepreneurship education and components of the 21st century digital capabilities. The method in this study uses a quantitative approach. Research analysis using Structural Equation Model (SEM) with questionnaire instruments and respondents are vocational students. The results showed the integration of 21st-century digital skills in entrepreneurship education had a positive and significant effect on increasing entrepreneurial competence in vocational students.

Keywords: Digital Skills, Entrepreneurship Education, Entrepreneurial Competence. 


\section{PENDAHULUAN}

Perkembangan teknologi berlangsung cepat dalam satu dekade terakhir. Perkembangan tersebut terus mempengaruhi pada semua aspek kehidupan. Pada akhirnya, terjadilah disrupsi teknologi. Disrupsi yang semakin meluas sehingga menyebabkan terciptanya revolusi industri 4.0 (Susianna, 2014). Isu utama pada revolusi industri ke empat ini adalah cyber physical system, internet of things, dan bio-technology (Claro et al., 2012). Pendidikan tidak lepas dari perubahan ini. Semua aspek pendidikan, mengalami perubahan baik dalam kurikulum, model, sampai media pembelajaran yang digunakan. Selain aspek pembelajaran, kompetensi pendidik dan peserta didik juga mengalami perubahan. Banyak teori yang menjelaskan tentang perubahan dalam bidang pendidikan ini. Pendidikan pada era sekarang biasa disebut dengan $21^{\text {st }}$ Century Teaching atau pembelajaran abad 21 (Zubaidah, 2016). Berdasarkan penelitian terdahulu dari (Fong, Sidhu, \& Fook, 2014) yang menemukan bahwa pada pembelajaran abad 21 terdapat kompetensi yang perlu diakomodasikan yaitu kompetensi bekerja secara kolaboratif, kompetensi otonomi seumur hidup, kompetensi teknologi informasi dan komunikasi (TIK), kompetensi berpikir kritis dan kreatif, kompetensi komunikasi dan berbahasa Inggris, dan terakhir adalah kompetensi kewirausahaan. Beberapa kompetensi tersebut diintegrasikan pada pembelajaran di sekolah. Salah satunya adalah kompetensi kewirausahaan. Pada sekolah, terdapat mata pelajaran pendidikan kewirausahaan yang sekarang menjadi pendidikan prakarya dan kewirausahaan pada pendidikan Sekolah Menengah Atas (SMA) dan produk kreatif dan kewirausahaan pada pendidikan Sekolah Menengah Kejuruan (SMK) (Wirandana \& Hidayati, 2017).

Pendidikan kewirausahaan mempunyai dua tujuan, yaitu tujuan jangka pendek dan jangka panjang. Tujuan jangka pendek yaitu menumbuhkan minat berwirausaha pada peserta didik. Kedua, tujuan jangka panjang kewirausahaan adalah untuk mengurangi tingkat pengangguran (Mitchelmore \& Rowley, 2010). Dilihat pada tujaun jangka pendek, jumlah wirausaha meningkat dari $1,67 \%$ menjadi $3,10 \%$ dari total penduduk Indonesia sebanyak 225 juta jiwa pada tahun 2018 (Data sekunder darti Badan Pusat Statistik, 2019). Jumlah ini masih sangat jauh dibandingkan negara maju seperti Amerika dan Jepang yang mempunya wirausaha lebih dari $12 \%$ dari total penduduk. Berdasarkan tujuan jangka panjang, pengangguran di Indonesia turun dari 7,04 juta jiwa yang masih menganggur menjadi 6,87 juta. Lulusan SMK masih menjadi lulusan dengan pengangguran terbanyak yaitu $8,92 \%$ dari 6,87 juta pengangguran. Hal tersebut tidak sesuai dengan tujuan SMK untuk menciptakan lulusan siap kerja. Kondisi tingkat pengangguran ini tidak jauh berbeda dengan provinsi Jawa Tengah dengan persentase tertinggi dari lulusan SMK sebanyak $10,85 \%$ dari total pengangguran di Jawa Tengah.

Apabila dilihat berdasarkan status pekerjaan, lulusan SMK terbanyak bekerja sebagai karyawan $(55,8 \%$ dari total penduduk lulusan SMK yang bekerja). Terdapat dua sisi tujuan yang membuat lulusan SMK perlu diperhatikan. Sisi pertama, data tersebut menunjukkan tujuan lulusan SMK siap kerja mulai menunjukkan peningkatan, tetapi di sisi lain sikap kewirausahaan dengan tujuan jangka panjang terciptanya lapangan pekerjaan 
baru sangat rendah karena wirausaha tidak termasuk dalam status pekerjaan utama lulusan SMK per Agustus 2018 (Data BPS, 2019). Kondisi penduduk yang bekerja sebagai wirausaha tersebut sama jika dilihat dalam kabupaten di karesidenan Surakarta. Kabupaten Wonogiri menempati posisi terendah penduduk dengan profesi sebagai wirausaha yaitu sebesar $14,70 \%$ dari total tenaga kerja.

Hasil tersebut menggambarkan minat wirausaha di Wonogiri rendah. Data tersebut juga didukung dengan kualitas SDM yang rendah dengan nilai Indeks Pembangunan Manusia (IPM) hanya sebesar 68,66 (lebih rendah dari rata-rata IPM Indonesia). Berdasarkan permasalah tersebut dan relevansinya terhadap salah satu keterampilan abad 21 yaitu kompetensi kewirausahaan, observasi awal dilakukan pada siswa SMK yang sudah menjalani pendidikan kewirausahaan. Instrumen penelitian pada observasi awal menggunakan kuesioner hasil adaptasi dari Mojab, Zaefarian, \& Azizi (2011). Observasi awal dilaksanakan pada dua SMK favorit di kabupaten Wonogiri yaitu SMKN 1 Wonogiri dan SMKN 2 Wonogiri dengan jumlah responden 50 peserta didik. Hasil observasi menunjukkan rata-rata jawaban peserta didik terhadap kompetensi kewirausahaan adalah 3 (rendah). Kompetensi kewirausahaan pada peserta didik dapat dipengaruhi oleh beberapa faktor. Pertama, kewirausahaan yang berbasis sosial dengan hubungannya dalam membangun pengalaman kewirausahaan, proses dalam kehidupan sehari-hari, dan proses belajar dimanis serta hasil belajar yang dapat diukur dapat membangun kompetensi kewirausahaan (Jensen, 2014). Kedua, pendidikan kewirausahaan yang memadukan pemahaman bisnis dan teknologi sangat berpengaruh terhadap proses pembelajaran kewirausahaan dan membangun kemampuan wirausaha bagi pelajar (Shih \& Huang, 2017).

Berbagai masalah-masalah tersebut maka tujuan penelitian ini adalah sebagai berikut: (1) Mengetahui pengaruh positif dan signifikan keterampilan digital abad 21 terhadap pendidikan kewirausahaan, (2) Mengetahui pengaruh positif dan signifikan keterampilan digital abad 21 terhadap kompetensi efektifitas personal kewirausahaan, (3) Mengetahui pengaruh positif dan signifikan keterampilan digital abad 21 terhadap kompetensi akademik kewirausahaan, (4) Mengetahui pengaruh positif dan signifikan keterampilan digital abad 21 terhadap kompetensi efektivitas personal kewirausahaan yang dimediasi oleh pendidikan kewirausahaan, (5) Mengetahui pengaruh positif dan signifikan keterampilan digital abad 21 terhadap kompetensi akademik kewirausahaan yang dimediasi oleh pendidikan kewirausahaan, (6) Mengetahui pengaruh positif dan signifikan pendidikan kewirausahaan terhadap kompetensi efektivitas personal kewirausahaan, dan (7) Mengetahui pengaruh positif dan signifikan terhadap kompetensi akademik kewirausahaan.

\section{Kompetensi kewirausahaan}

kewirausahaan merupakan sikap dan perilaku seseorang dalam menerapkan kreativitas, inovasi, pengambil risiko dalam upaya untuk mengasumsikan kebutuhan finansial, risiko sosial, dan menerima balas jasa dan kepuasan serta kebebasan secara personal (Riyani et al., 2005; Hisrich, Peters, \& Shepherd, 2017). kompetensi kewirausahaan merupakan kecakapan yang memadai untuk melakukan suatu tugas atau sebagai kemampuan untuk 
memiliki keterampilan dan kecakapan yang disyaratkan pada sikap dan perilaku seseorang dalam menerapkan kreativitas, inovasi, pengambil risiko dalam upaya untuk mengasumsikan kebutuhan finansial, risiko sosial, dan menerima balas jasa dan kepuasan serta kebebasan secara personal (Hayton \& Kelley, 2006; Mitchelmore \& Rowley, 2010; Chiru, Tachiciu, \& Ciuchete, 2012; Sathe, 2013). Kompetensi ini mempunyai hubungan dengan pendidikan yang dialami seseorang. Terbukti bahwa penerapan konsep kewirausahaan pada pendidikan seseorang mampu mempengaruhi kompetensi dari segi psikologik (Shir, Nikolaev, \& Wincent, 2018).

Kompetensi kewirausahaan tidak bisa diukur dengan tepat tanpa mengetahui dimensi pembentuknya. Kompetensi kewirausahaan dibagi menjadi dua kelompok besar yaitu kompetensi efektivitas personal dan kompetensi akademik (Mojab et al., 2011). Dimensi kompetensi efektivitas personal kewirausahaan dan sekaligus menjadi indikator variabelnya adalah keterampilan interpersonal dan kerjasama tim, inisiatif, mudah beradaptasi dan fleksibel, pengambilan risiko, dan keinginan untuk belajar (Mojab et al., 2011; Robles \& Zárraga, 2015). Dimensi pada variabel kompetensi akademik kewirausahaan adalah membaca dan menulis, matematika, teknologi dan sains, komunikasi, berpikir kritis dan analitis (Mojab et al., 2011; Robles \& Zárraga, 2015).

\section{Pendidikan kewirausahaan}

Perkembangan semangat kewirausahaan telah menghasilkan subjek dari banyak artikel penelitian sebagai sarana untuk menghasilkan proyek bisnis (Sánchez, 2011). Pendidikan kewirausahaan dikategorikan sebagai program praktis yang unik karena pada implementasinya menumbuhkan tidak hanya keterampilan praktis, tetapi lebih jauh lagi pada pembentukan pola pikir yang mungkin berbeda pada peserta didik (Robinson, Neergaard, Tanggard, \& Kreuger, 2016). Klein \& Bullock (2006) menyatakan bahwa program kewirausahaan bertujuan untuk tidak hanya mengajarkan peserta didik tentang akuntansi, manajemen proyek dan pemasaran, tetapi juga menimbulkan sifat ilusif seperti keberanian, inovasi, dan kreativitas yang sulit diukur. Keluaran atau hasil yang khas serta ideal dalam proses pendidikan kewirausahaan adalah seorang individu dengan kemampuan untuk melihat dan mengevaluasi peluang bisnis, mengumpulkan sumber daya yang diperlukan untuk mendapatkan keuntungan, dan memulai tindakan yang tepat untuk memastikan kesuksesan berwirausaha (Solesvik, 2013). Pendidikan kewirausahaan pada abad 21 sering dikaitkan dengan integrasi teknologi dalam pembelajaran (Shih \& Huang, 2017). Hal ini karena berbagai keterampilan, pengetahuan, dan sikap yang harus ada dalam pendidikan kewirausahaan maka perlu tertanam secara koheren dan komprehensif dalam kurikulum nasional. Allegra, Gentile, La Guardia, Dal Grande, \& Ottaviano (2014) menemukan salah satu cara untuk mengakomodasi dari keterampilan pada pendidikan kewirausahaan melalui pendidikan berbasis permainan (Game Based Learning) yang merupakan model dengan menerapkan teknologi.

Pendidikan kewirausahaan terdapat beberapa komponen yang saling berhubungan. Menurut Tung (2011) yang mengambil pendapat dari Johannison menyatakan bahwa ada lima komponen pendidikan kewirausahaan yaitu know- 
what (entrepreneurial knowledge), know-why (value and motives), know-who (social interaction), know-how (entrepreneurial skills and abilities), dan knowwhen (intuition, the right time to startup). Kelima komponen pendidikan kewirausahaan dapat diterapkan untuk menjadi alat pengukur pendidikan kewirausahaan pada peserta didik tingkat SMA, SMK, atau MA kecuali knowwhen. Komponen tersebut tidak bisa digunakan karena hanya bisa diterapkan bagi pengusaha yang sudah menjalani usaha, berbeda dengan peserta didik yang belum menjadi seorang wirausaha. Pendidikan kewirausahaan mempunyai hubungan dengan kompetensi kewirausahaan. Penelitian dari Din, Anuar, \& Usman (2016) menemukan bahwa kompetensi kewirausahaan secara umum berpengaruh secara signifikan terhadap efektivitas dari proses pembelajaran kewirausahaan.

\section{Keterampilan digital abad 21}

Perkembangan zaman menuntut kualitas manusia berubah dan semakin berkembang. Salah satu kualitas yang harus dimiliki pada abad 21 ini adalah keterampilan abad 21 atau yang sering disebut dengan $21^{\text {st }}$ Century Skills. Perkembangan keterampilan ini dapat diterapkan pada berbagai aspek kehidupan. Salah satu implementasi keterampilan abad 21 adalah pada Teknologi Informasi dan Komunikasi (TIK) sebagai corak utama perkembangan di revolusi industri 4.0. Teknologi informasi dan komunikasi merupakan inti dari perubahan ekonomi yang cepat. Hal ini tidak sepenuhnya berjalan secara relevan karena dibutuhkan keterampilan dari manusia untuk menciptakan modal manusia dalam angkatan kerja yang berkualitas (Anderson, 2008). Keterampilan digital abad 21 mempunyai komponen pembangun yang merupakan indikator seseorang telah memiliki keterampilan tersebut. Keterampilan digital abad 21 terdiri dari teknikal mengoperasikan teknologi, manajemen informasi, komunikasi, kolaborasi, kreativitas, berpikir kritis, penyelesaian masalah (van Laar, van Deursen, van Dijk, \& de Haan, 2017; van Laar, van Deursen, van Dijk, \& de Haan, 2018). Pada penelitian ini teknikal operasi tidak digunakan karena tidak memenuhi standar validitas dan reliabilitas. Hal ini disebabkan peserta didik sudah bisa mengoperasikan teknologi digital. Pengembangan pedidikan kewirausahaan diperlukan teknologi tidak terkecuali untuk meningkatkan keluaran hasil pendidikan kewirausahaan diperlukan pengetahuan dan keterampilan teknologi khususnya digital (Shih \& Huang, 2017). Penggunaan teknologi digital terbukti dapat meningkatkan kebiasaan untuk berwirausaha (Delacroix, Parguel, \& BenoitMoreau, 2018).

\section{METODE PENELITIAN}

Pendekatan penelitian menggunakan pendekatan kuantitatif dengan metode penelitian kuantitatif deskriptif. Ada tiga jenis variabel pada penelitian ini. Variabel tersebut adalah variabel eksogen, variabel mediasi, dan variabel endogen. Variabel eksogen pada penelitian ini adalah keterampilan digital abad 21. Variabel mediasi adalah pendidikan kewirausahaan dan variabel endogen adalah kompetensi efektivitas personal kewirausahaan dan kompetensi akademik kewirausahaan. Indikator variabel keterampilan digital abad 21 
terdiri dari manajemen informasi, komunikasi, kolaborasi, berpikir kritis, kreativitas, dan penyelesaian masalah. Indikator dari variabel pendidikan kewirausahaan terdiri dari know what, know why, know who, dan know how. Indikator variabel kompetensi efektivitas personal kewirausahaan terdiri dari keterampilan interpersonal dan kerjasama tim, inisiatif, ambisi, mudah beradaptasi dan fleksibel, pengambilan risiko, keinginan untuk belajar. Terakhir, indikator kompetensi akademik kewirausahaan terdiri dari membaca dan menulis, matematika, teknologi dan sains, komunikasi, berpikir kritis dan analitis.

Populasi pada penelitian ini adalah semua peserta didik SMK kelas 12 di Wonogiri tahun 2019 dengan jumlah 1935 peserta didik. Sampel diambil dari 6 SMK yang memiliki akreditasi A yaitu SMK N 1 Wonogiri, SMK N 2 Wonogiri, SMK Bhakti Mulia Wonogiri, SMK N 1 Giritontro, SMK N 1 Kismantoro, dan SMK Pancasila 1 Wonogiri. Sampling pada penelitian ini menggunakan non probability sampling dengan teknik purposive sampling. Jumlah sampel yang diambil adalah sebesar 210 berdasarkan teori sampling pada penelitian multivariat dari Roscoe dalam Sekaran (2006) yang menyatakan bahwa jumlah sampel pada penelitian multivariat terdiri dari 5-10 kali variabel dengan asumsi satu variabel satu indikator. Pada penelitian ini terdapat 21 indikator $\mathrm{x} 10$ (jumlah maksimal yang diambil) menjadi 210 sampel dengan pembagian proporsional pada Tabel 1 .

Tabel 1. Jumlah Responden Masing-Masing Sekolah

\begin{tabular}{llcc}
\hline No & \multicolumn{1}{c}{ Nama Sekolah } & $\begin{array}{c}\text { Jumlah Peserta Didik } \\
\text { Kelas XII }\end{array}$ & $\begin{array}{c}\text { Jumlah } \\
\text { Responden }\end{array}$ \\
\hline 1 & SMK Negeri 1 Wonogiri & 392 & 43 \\
2 & SMK Negeri 2 Wonogiri & 527 & 57 \\
3 & SMK Bhakti Mulia & 167 & 18 \\
& Wonogiri & 207 & 22 \\
5 & SMK Negeri 1 Giritontro & 164 & 18 \\
6 & SMK Negeri 1 Kismantoro & 478 & 52 \\
\hline \multicolumn{2}{r}{ SMK Pancasila 1 Wonogiri } & $\mathbf{1 9 3 5}$ & $\mathbf{2 1 0}$ \\
\hline
\end{tabular}

Teknik analisis data pada penelitian ini menggunakan Structural Equation Model (SEM) dengan berbantukan SPSS AMOS dan SPSS Process. Pengambilan data menggunakan kuesioner dengan tujuh skala sikap yaitu sangat setuju (SS), setuju (S), agak setuju (AS), ragu-ragu (R), agak tidak setuju (ATS), tidak setuju (TS), sangat tidak setuju (STS).

\section{HASIL PENELITIAN DAN PEMBAHASAN}

Sebelum dianalisis, kuesioner perlu diuji validitas dan reliabilitas. Uji validitas dan reliabilitas dilakukan dengan jumlah minimal 30 responden. Uji validitas menggunakan rumus product moment dari Pearson. Hasil uji validitas dari 105 item pernyataan adalah $\mathrm{R}_{\text {hitung }}$ pada setiap item pernyataan $>\mathrm{R}_{\text {tabel }}$ $(0,36)$. Hasil tersebut dapat diartikan bahwa semua item pernyataan dinyatakan 
valid. Uji reliabilitas menggunakan nilai cronbach's alpha. Item pernyataan dinyatakan reliabel apabila nilai cronbach's alpha $>0,60$. Hasil uji reliabilitas menunjukkan bahwa semua item pernyataan memiliki nilai cronbach's alpha lebih besar dari 0,60. Hasil tersebut menggambarkan bahwa semua item pernyataan dinyatakan reliabel.

Setelah kuesioner dinyatakan valid dan reliabel, maka dapat melakukan penelitian secara empiris di lapangan. Data yang diperoleh kemudian dianalisis menggunakan model SEM dengan bantuan SPSS AMOS. Ringkasan hasil analaisis tersebut dapat dilihat pada gambar 1.

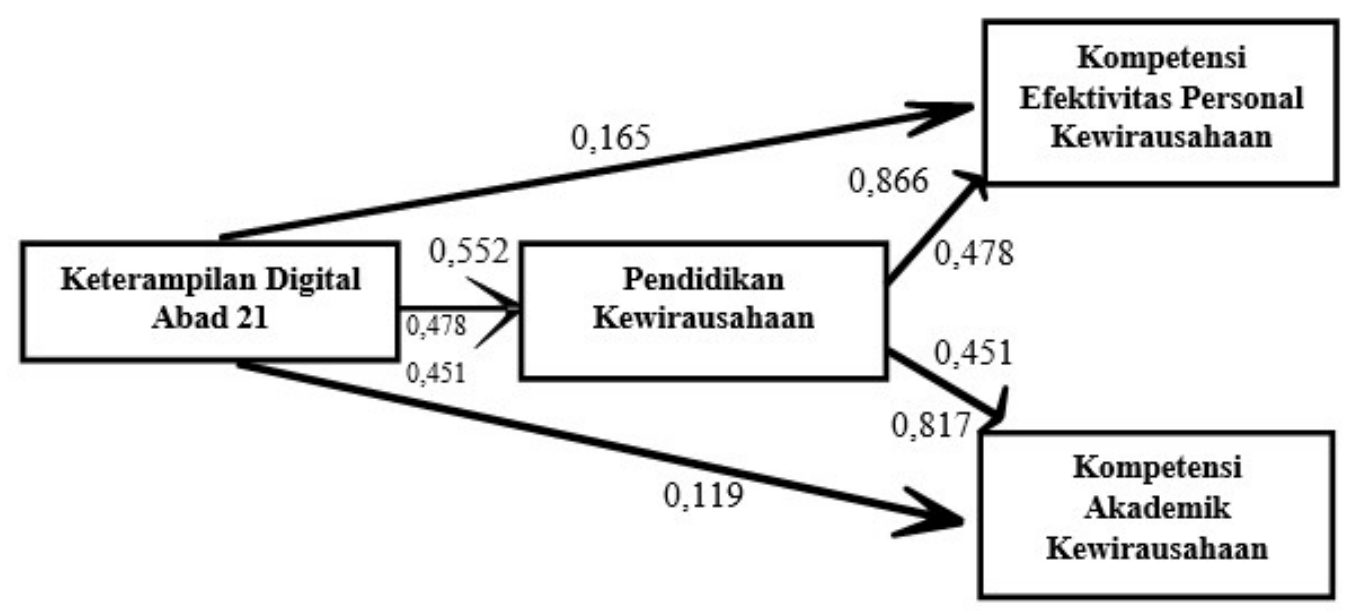

Gambar 1. Hasil Analisis Jalur pada Model

Hasil dari analisis jalur menunjukkan bahwa semua jalur berhubungan secara positif dan signifikan (Tabel 2.). Nilai $p$-value harus bersyarat $<0,05$ agar jalur dinyatakan signifikan Hipotesis pertama terdukung dengan nilai $p$ value 0,000 yang berarti signifikan dan nilai standardized beta 0,552 yang berarti berhubungan secara positif sebesar 55,2\%. Hasil ini menunjukkan bahwa terdapat hubungan yang positif dan signifikan keterampilan digital abad 21 terhadap pendidikan kewirausahaan. Hipotesis kedua terdukung dengan nilai $p$-value 0,001 yang berarti signifikan dan nilai standardized beta 0,165 yang berarti berhubungan secara positif sebesar 16,5\%. Hasil ini menunjukkan bahwa terdapat hubungan secara langsung yang positif dan signifikan keterampilan digital abad 21 terhadap kompetensi efektifitas personal. Hipotesis ketiga terdukung dengan nilai p-value 0,048 yang berarti signifikan dan nilai standardized beta 0,119 yang berarti berhubungan secara positif sebesar 11,9\%. Hasil ini menunjukkan bahwa terdapat hubungan secara langsung yang positif dan signifikan keterampilan digital abad 21 terhadap kompetensi akademik kewirausahaan. Hipotesis keempat terdukung dengan nilai $p$-value 0,000 yang berarti signifikan dan nilai standardized beta 0,478 yang berarti berhubungan secara positif sebesar $47,8 \%$. Hasil ini menunjukkan bahwa terdapat hubungan secara yang positif dan signifikan keterampilan digital abad 21 terhadap kompetensi efektivitas personal kewirausahaan yang dimediasi oleh pendidikan kewirausahaan. Hipotesis kelima terdukung dengan 
nilai $p$-value 0,000 yang berarti signifikan dan nilai standardized beta 0,451 yang berarti berhubungan secara positif sebesar $45,1 \%$. Hasil ini menunjukkan bahwa terdapat hubungan secara yang positif dan signifikan keterampilan digital abad 21 terhadap kompetensi akamdemik kewirausahaan yang dimediasi oleh pendidikan kewirausahaan. Hipotesis keenam terdukung dengan nilai $p$-value 0,000 yang berarti signifikan dan nilai standardized beta 0,866 yang berarti berhubungan secara positif sebesar 86,6\%. Hasil ini menunjukkan bahwa terdapat hubungan secara yang positif dan signifikan pendidikan kewirausahaan terhadap kompetensi efektivitas personal kewirausahaan. Hipotesis ketujuh terdukung dengan nilai $p$-value 0,000 yang berarti signifikan dan nilai standardized beta 0,817 yang berarti berhubungan secara positif sebesar $81,7 \%$. Hasil ini menunjukkan bahwa terdapat hubungan secara yang positif dan signifikan pendidikan kewirausahaan terhadap kompetensi efektivitas personal kewirausahaan.

Tabel 2. Hasil Regression Weight

\begin{tabular}{lcccl}
\hline \multicolumn{1}{c}{ Jalur } & $\begin{array}{c}\text { Unstand } \\
\text { ardized } \\
\text { Beta }\end{array}$ & $\begin{array}{c}\text { Standardized } \\
\text { Beta }\end{array}$ & $\begin{array}{c}\text { p- } \\
\text { value }\end{array}$ & Keputusan \\
\hline Variabel X $\rightarrow$ Variabel M & 0,249 & 0,552 & 0,000 & Signifikan \\
Variabel X $\rightarrow$ Variabel Y1 & 0,050 & 0,165 & 0,001 & Signifikan \\
Variabel X $\rightarrow$ Variabel Y2 & 0,043 & 0,119 & 0,048 & Signifikan \\
Variabel X $\rightarrow$ Variabel M & - & 0,478 & 0,000 & Signifikan \\
$\rightarrow$ Variabel Y1 & & & & \\
Variabel X $\rightarrow$ Variabel M & - & 0,451 & 0,000 & Signifikan \\
$\rightarrow$ Variabel Y2 & & & & \\
Variabel M $\rightarrow$ Variabel Y1 & 0,582 & 0,866 & 0,000 & Signifikan \\
Variabel M $\rightarrow$ Variabel Y2 & 0,647 & 0,817 & 0,000 & Signifikan \\
\hline
\end{tabular}

Setelah analisis jalur didapatkan, langkah selanjutnya adalah uji kesesuaian model atau goodness off fit test. Berikut adalah hasil uji kesesuaian model:

Tabel 3. Hasil Pengukuran Tingkat Kesesuaian

\begin{tabular}{ccc}
\hline Ukuran goodness off fit & Batas Penerimaan goodness off fit & Hasil \\
\hline TLI & $0,80 \leq \mathrm{TLI} \leq 1$ & 0,884 \\
CFI & $0,80 \leq \mathrm{CFI} \leq 1$ & 0,898 \\
NFI & $0,80 \leq \mathrm{NFI} \leq 1$ & 0,854 \\
\hline
\end{tabular}

Tabel 3. menjelaskan tentang pengukuran kesesuaian model. TLI atau Tucker-Lewis Index dan NFI atau Normed Fit Index yang dapat digunakan untuk mengukur kecocokan incremental yaitu membandingkan model yang diusulkan dengan model dasar. Nilai TLI adalah 0,884 dan nilai NFI adalah 0,854 yang menunjukkan model dalam kriteria good fit (kesesuaian yang baik). Alat ukur terakhir yaitu Comparative Fit Index (CFI) yang juga merupakan indeks kesesuaian incremental dan sangat dianjurkan karena tidak sensitive dengan jumlah sampel. Nilai CFI adalah 0,898 dan termasuk dalam kriteria 
good fit (kesesuaian yang baik). Kesimpulannya adalah secara keseluruhan model persamaan analisis jalur yang digunakan dapat diterima.

\section{Keterampilan digital abad 21 terhadap pendidikan kewirausahaan}

Pengaruh variabel keterampilan digital abad 21 tersebut adalah sebesar $55,2 \%$ terhadap variabel pendidikan kewirausahaan. Nilai tersebut menunjukkan bahwa peserta didik yang mempunyai keterampilan digital abad 21 tinggi, maka pemahaman dan aktualisasi diri terhadap kewirausahaan semakin tinggi. Teknologi sudah mewarnai bahkan mengubah tatanan kehidupan manusia setiap hari saat ini. Pada akhirnya, dampak teknologi terutama digital memiliki dampak mengenai inovasi, teknologi kewirausahaan, dan proses penciptaan usaha baru dan memodifikasi semua aspek kehidupan (Rippa \& Secundo, 2018). Hal ini menandakan bahwa teknologi khususnya digital bisa diterapkan dalam berbagai tatapan bahkan proses dalam pembelajaran tanpa terkecuali pada pembelajaran kewirausahaan. Internet berpengaruh signifikan terhadap proses kewirausahaan (Asghari \& Gedeon, 2010).

\section{Keterampilan digital abad 21 terhadap kompetensi kewirausahaan secara langsung}

Besaran pengaruh variabel keterampilan digital abad 21 terhadap variabel kompetensi efektivitas personal kewirausahaan adalah 16,5\%. Hasil tersebut sesuai dengan temuan Hsieh \& Wu (2018: 1) yang menyatakan bahwa dalam pengembangan inovasi dalam kewirausahaan diperlukan integrasi teknologi. Penelitian tersebut memberikan beberapa saran untuk penelitian selanjutnya. Beberapa isu utama yang bisa diangkat adalah pengembangan jenis platform inovasi untuk pengusaha, platform kontrol pengetahuan dan perlindungan kewirausahaan, pengaktifan dan penghambat mengadopsi platform inovasi kewirausahaan, dan pertimbangan strategi dalam kewirausahaan melalui platform inovasi. Jejak kaki digital yang pernah dijelajahi seseorang bisa mengungkapkan kepribadian kewirausahaan seseorang. Hal ini seperti temuan dari Obschonka et al. (2012) yang menyatakan bahwa kepribadian kewirausahaan dari berbagai pemimpin bisnis di dunia dapat diungkapkan melalui jejak digital dari twitter. Sesuai dengan besaran pengaruhnya, personal kewirausahaan dipengaruhi oleh beberapa faktor dan keterampilan digital abad 21 hanya berpengaruh sebesar $16,5 \%$.

Besaran pengaruh variabel keterampilan digital abad 21 terhadap variabel kompetensi akademik kewirausahaan adalah 11,9\%. Hal ini menunjukkan bahwa keterampilan dalam menggunakan teknologi digital berpengaruh terhadap kompetensi kewirausahaan yang dimiliki seseorang. Teknologi digital yang dimaksud pada pembahasan di atas dapat berupa artefak digital, platform digital, dan infrastruktur digital (Nzembayie, Buckley, \& Cooney, 2019). Penggunaan teknologi digital terbukti dapat meningkatkan kebiasaan untuk berwirausaha (Delacroix, Parguel, \& Benoit-Moreau, 2018). Penggunaan teknologi digital pada kewirausahaan tidak hanya sebagai media maupun infrastruktur dalam proses pembelajaran tetapi dapat menjadi sarana membentuk kepribadian kewirausahaan (Hull, Hair, DeMartino, Hung, \& Perotti, 2007; Nambisan, 2017). 
Keterampilan digital abad 21 terhadap kompetensi kewirausahaan dengan mediasi pendidikan kewirausahaan

Besaran pengaruh variabel keterampilan digital abad 21 yang dimediasi oleh variabel pendidikan kewirausahaan terhadap variabel kompetensi efektivitas personal kewirausahaan adalah 47,8 \%. Pada akhirnya, dampak teknologi terutama digital memiliki dampak mengenai inovasi, teknologi kewirausahaan, dan proses penciptaan usaha baru dan memodifikasi semua aspek kehidupan (Rippa \& Secundo, 2018). Hal ini menandakan bahwa teknologi khususnya digital bisa diterapkan dalam berbagai tatapan bahkan proses dalam pembelajaran tanpa terkecuali pada pembelajaran kewirausahaan. Internet berpengaruh signifikan terhadap proses kewirausahaan (Asghari \& Gedeon, 2010).

Besaran pengaruh variabel keterampilan digital abad 21 yang dimediasi oleh variabel pendidikan kewirausahaan terhadap variabel kompetensi akademik kewirausahaan adalah 45,1 \%. Hal ini menandakan bahwa teknologi khususnya digital bisa diterapkan dalam berbagai tatapan bahkan proses dalam pembelajaran tanpa terkecuali pada pembelajaran kewirausahaan. Internet berpengaruh signifikan terhadap proses kewirausahaan (Asghari \& Gedeon, 2010). Semakin tinggi kompetensi yang dicapai, maka semakin efektif pula pembelajaran kewirausahaan yang telah diterapkan. Pada penelitian tersebut komponen kompetensi yang dipakai adalah rencana bisnis, pengambilan risiko, efikasi diri, penghargaan, dan locus of control. Masih banyak lagi penelitian yang menyatakan bahwa pendidikan kewirausahaan dan kompetensi kewirausahaan mempunyai hubungan yang kuat dan berpengaruh signifikan (Chiru et al., 2012: 4011; Shir et al., 2018; Robles \& Zárraga, 2015; Siwan Mitchelmore \& Rowley, 2010; Mojab et al., 2011). Temuan dalam hasil penelitian ini mencakup pentingnya integrasi keterampilan digital abad 21 pada pendidikan kewirausahaan terhadap kompetensi kewirausahaan. Perlu adanya proses pembelajaran yang bisa mengakomodasikan keterampilan digital abad 21 .

\section{Pendidikan kewirausahaan terhadap kompetensi kewirausahaan}

Besaran pengaruh variabel pendidikan kewirausahaan terhadap variabel kompetensi efektivitas personal kewirausahaan adalah 86,6 \%. Proses pembelajaran pada pendidikan kewirausahaan mempunyai hubungan yang erat dengan kompetensi yang hendak dicapai dalam pembelajaran kewirausahaan tersebut. Sifat pendidikan kewirausahaan yang merupakan perpaduan tiga komponen yaitu praktis, akademik, dan sikap secara komprehensif membuat tujuan pendidikan ini lebih luas. Penelitian dari Din, Anuar, \& Usman (2016: 119) menemukan bahwa kompetensi kewirausahaan secara umum berpengaruh secara signifikan terhadap efektivitas dari proses pembelajaran kewirausahaan. Pada konteks ini berarti efektivitas pendidikan kewirausahaan tergantung pada kompetensi yang dicapai. Semakin tinggi kompetensi yang dicapai, maka semakin efektif pula pembelajaran kewirausahaan yang telah diterapkan.

Besaran pengaruh variabel pendidikan kewirausahaan terhadap variabel kompetensi akademik kewirausahaan adalah 81,7\%. Pada penelitian Din, Anuar, \& Usman (2016) komponen kompetensi yang dipakai adalah rencana bisnis, pengambilan risiko, efikasi diri, penghargaan, dan locus of control. Masih banyak lagi penelitian yang menyatakan bahwa pendidikan 
kewirausahaan dan kompetensi kewirausahaan mempunyai hubungan yang kuat dan berpengaruh signifikan (Chiru et al., 2012; Shir et al., 2018; Robles \& Zárraga, 2015; Siwan Mitchelmore \& Rowley, 2010; Mojab et al., 2011). Temuan pada penelitian ini adalah faktor terbesar dalam pembentukan kompetensi kewirausahaan adalah melalui pendidikan kewirausahaan. Sedangkan keterampilan digital abad 21 yang diintegrasikan di dalamnya berpengaruh positif dan signifikan terhadap pembentukan kompetensi kewirausahaan pada peserta didik.

\section{SIMPULAN}

Berdasarkan hasil penelitian dan analisis yang telah dilakukan, dapat disimpulkan bahwa terdapat pengaruh yang signifikan antara keterampilan digital abad 21 terhadap kompetensi efektivitas personal kewirausahaan dan kompetensi akademik kewirausahaan baik secara langsung maupun dimediasi oleh pendidikan kewirausahaan. Hasil ini dapat terlihat pada hasil penelitian yang menunjukkan bahwa terdapat pengaruh yang positif dan signifikan keterampilan digital abad 21 terhadap pendidikan kewirausahaan peserta didik SMK di Kabupaten Wonogiri. Ke-dua, hasil penelitian yang menunjukkan bahwa terdapat pengaruh yang positif dan signifikan keterampilan digital abad 21 terhadap kompetensi efektivitas personal kewirausahaan peserta didik SMK di Kabupaten Wonogiri. Ke-tiga, hasil penelitian yang menunjukkan bahwa terdapat pengaruh yang positif dan signifikan keterampilan digital abad 21 terhadap kompetensi akademik kewirausahaan peserta didik SMK di Kabupaten Wonogiri. Ke-empat, hasil penelitian yang menunjukkan bahwa terdapat pengaruh yang positif dan signifikan keterampilan digital abad 21 terhadap kompetensi efektivitas personal kewirausahaan peserta didik SMK di Kabupaten Wonogiri yang dimediasi oleh pendidikan kewirausahaan. Ke-lima, hasil penelitian yang menunjukkan bahwa terdapat pengaruh yang positif dan signifikan keterampilan digital abad 21 terhadap kompetensi akademik kewirausahaan peserta didik SMK di Kabupaten Wonogiri yang dimediasi oleh pendidikan kewirausahaan. Selanjutnya, hasil penelitian yang menunjukkan bahwa terdapat pengaruh yang positif dan signifikan pendidikan kewirausahaan terhadap kompetensi efektivitas personal kewirausahaan peserta didik SMK di Kabupaten Wonogiri. Terakhir, hasil penelitian yang menunjukkan bahwa terdapat pengaruh yang positif dan signifikan pendidikan kewirausahaan terhadap kompetensi akademik kewirausahaan peserta didik SMK di Kabupaten Wonogiri. Faktor atau indikator yang dominan berpengaruh pada variabel keterampilan digital abad 21 adalah indikator berpikir kritis dan kreativitas. Indikator pada pendidikan kewirausahaan yang sangat dominan adalah know who atau aktualisasi diri terhadap kewirausahaan dan know how atau pengetahuan megenai cara berwirausaha. Indikator yang signifikan dan dominan mempengaruhi variabel kompetensi efektivitas personal kewirausahaan adalah inisiatif lalu mudah beradaptasi dan fleksibel. Terakhir, indikator yang merupakan penyumbang signifikan terbesar pada variabel kompetensi akademik kewirausahaan adalah teknologi dan sains serta komunikasi. 
Penelitian kedepan perlu dikonfirmasi ulang melalui penelitian yang lebih spesifik dengan menguji satu per satu faktor dan indikator untuk menemukan faktor maupun indikator yang dapat diperbandingkan besar kecil pengaruhnya terhadap variabel yang relevan. Penelitian selanjutnya juga disarankan melalui pengembangan produk pembelajaran agar pengalaman empiris dari hasil temuan pada penelitian ini bisa dibuktikan.

\section{DAFTAR RUJUKAN}

Allegra, M., Gentile, M., La Guardia, D., Dal Grande, V., \& Ottaviano, S. (2014). A Game based Learning Model for Entrepreneurship Education. Procedia - Social and Behavioral Sciences, 141, 195-199. https://doi.org/10.1016/j.sbspro.2014.05.034

Anderson, R. (2008). Implications of the information and knowledge society for education. International handbook of information technology in primary and secondary education (J. Voogt \& G. Knezek, eds.). New York: Springer.

Asghari, R., \& Gedeon, S. (2010). Significance and Impact of Internet on the Entrepreneurial Process: E-Entrepreneurship and Completely Digital Entrepreneurship. Academic Conferences International Limited, 1-9.

Chiru, C., Tachiciu, L., \& Ciuchete, S. G. (2012). Psychological Factors, Behavioural Variables and Acquired Competencies in Entrepreneurship Education. Procedia - Social and Behavioral Sciences, 46, 4010-4015. https://doi.org/10.1016/j.sbspro.2012.06.188

Claro, M., Preiss, D. D., San Martín, E., Jara, I., Hinostroza, J. E., Valenzuela, S., \& Al., E. (2012). Assessment of 21 st century ICT skills in Chile: Test design and results from high school level students. Computers \& Education, 59(3), $1024-1053$. https://doi.org/http://dx.doi.org/10.1016/j.compedu.2012.04.004.

Delacroix, E., Parguel, B., \& Benoit-Moreau, F. (2018). Digital subsistence entrepreneurs on Facebook. Technological Forecasting and Social Change, (October 2017), 0-1. https://doi.org/10.1016/j.techfore.2018.06.018

Din, B. H., Anuar, A. R., \& Usman, M. (2016). The Effectiveness of the Entrepreneurship Education Program in Upgrading Entrepreneurial Skills among Public University Students. Procedia - Social and Behavioral Sciences, 224(August 2015), 117-123. https://doi.org/10.1016/j.sbspro.2016.05.413

Fong, L. L., Sidhu, G. K., \& Fook, C. Y. (2014). Exploring 21st century skills among postgraduates in Malaysia. Procedia - Social and Behavioral Sciences, 123, 130-138. https://doi.org/10.1016/j.sbspro.2014.01.1406 
Hayton, J. C., \& Kelley. (2006). A competency-based framework for promoting corporate entrepreneurship. Human Resource Management, 45(3), 407-427.

Hisrich, R. D., Peters, M. P., \& Shepherd, D. A. (2017). Entrepreneurship Tenth Edition. New York: McGraw-Hill Education.

Hsieh, Y.-J., \& Wu, Y. J. (2018). Entrepreneurship through the platform strategy in the digital era: Insights and research opportunities. Computers in Human Behavior. https://doi.org/10.1016/j.chb.2018.03.033

Hull, C. E., Hair, N., DeMartino, R., Hung, Y. T. C., \& Perotti, V. (2007). Taking advantage of digital opportunities: a typology of digital entrepreneurship. International Journal of Networking and Virtual Organisations, 4(3), 290. https://doi.org/10.1504/ijnvo.2007.015166

Jensen, T. L. (2014). A holistic person perspective in measuring entrepreneurship education impact - Social entrepreneurship education at the Humanities. International Journal of Management Education, 12(3), 349-364. https://doi.org/10.1016/j.ijme.2014.07.002

Klein, P., \& Bullock, B. (2006). can entrepreneurship be taught? Journal of Agricultural and Applied Economics, 38(2), 429-439.

Mitchelmore, S., \& Rowley, J. (2010). Entrepreneurial competencies: A literature review and development agenda. International Journal of Entrepreneurial Behaviour \& Research, 16(2), 92-111. https://doi.org/10.1108/13552551011026995

Mojab, F., Zaefarian, R., \& Azizi, A. H. D. (2011). Applying competency based approach for entrepreneurship education. Procedia - Social and Behavioral Sciences, 12, 436-447. https://doi.org/10.1016/j.sbspro.2011.02.054

Nambisan, S. (2017). Digital Entrepreneurship: Toward a Digital Technology Perspective of Entrepreneurship. Entrepreneurship: Theory and Practice, 41(6), 1029-1055. https://doi.org/10.1111/etap.12254

Nzembayie, K. F., Buckley, A. P., \& Cooney, T. (2019). Researching Pure Digital Entrepreneurship - A Multimethod Insider Action Research approach. Journal of Business Venturing Insights, 11(November), 1-10. https://doi.org/10.1016/j.jbvi.2018.e00103

Obschonka, M., Goethner, M., Silbereisen, R. K., \& Cantner, U. (2012). Social identity and the transition to entrepreneurship: the role of group identification with workplace peers. Journal of Vocational Behavior, 80(1), 137-147. 
Rippa, P., \& Secundo, G. (2018). Digital academic entrepreneurship: The potential of digital technologies on academic entrepreneurship. Technological Forecasting and Social Change, (November 2017), 0-1. https://doi.org/10.1016/j.techfore.2018.07.013

Riyani, A. L., Suwarsi, S., Karsono, Darustam, Sudarwanto, A. S., Purwono, J., ... Sulistyo, E. T. (2005). Dasar-Dasar Kewirausahaan (E. T. Sulistyo, ed.). Surakarta: UNS Press.

Robinson, S., Neergaard, H., Tanggard, L., \& Kreuger, N. (2016). New horizon in entrepreneurship education from teacher-led to student-centered learning. Education Training, 58(7), 661-683.

Robles, L., \& Zárraga, M. (2015). Key Competencies for Entrepreneurship. Procedia Economics and Finance, 23(October 2014), 828-832. https://doi.org/10.1016/S2212-5671(15)00389-5

Sánchez, J. (2011). Entrepreneurship: Introduction. Psicothema, 23(3), 424426.

Sathe, V. (2013). Corporate Entrepreneurship: Top Managers and New Business Creation. Cambridge: University Press, Cambridge.

Sekaran, U. (2006). Metodologi Penelitian untuk Bisnis. Jakarta: Salemba Empat.

Shih, T., \& Huang, Y. Y. (2017). A case study on technology entrepreneurship education at a Taiwanese research university. Asia Pacific Management Review, 22(4), 202-211. https://doi.org/10.1016/j.apmrv.2017.07.009

Shir, N., Nikolaev, B. N., \& Wincent, J. (2018). Entrepreneurship and wellbeing: The role of psychological autonomy, competence, and relatedness $\hat{z}$. Journal of Business Venturing, (March 2017), 0-1. https://doi.org/10.1016/j.jbusvent.2018.05.002

Solesvik, M. Z. (2013). Education + Training Article information : 55(3), 253271.

Susianna, N. (2014). Implementasi keterampilan abad 21 dalam kurikulum 2013. Integrasi Ketermpilan Abad 21 Dalam Kurikulum 2013 Untuk Mewujudkan Indonesia Jaya, 1-13.

Tung, L. C. (2011). The Impact of Entrepreneurship Education on Entrepreneurial Intention of Engineering Students. City University of Hongkong: Run-Run Show Library.

van Laar, E., van Deursen, A. J. A. M., van Dijk, J. A. G. M., \& de Haan, J. (2017). The relation between 21st-century skills and digital skills: 
A systematic literature review. Computers in Human Behavior, 72, 577588. https://doi.org/10.1016/j.chb.2017.03.010

van Laar, E., van Deursen, A. J. A. M., van Dijk, J. A. G. M., \& de Haan, J. (2018). 21st-century digital skills instrument aimed at working professionals: Conceptual development and empirical validation. Telematics and Informatics, 35(8), 2184-2200. https://doi.org/10.1016/j.tele.2018.08.006

Wirandana, E., \& Hidayati, S. (2017). Pengaruh pendidikan kewirausahaan terhadap niat berwirausaha. EDUKA Jurnal Pendidikan, Hukum, Dan Bisnis, 1(5), 75-86.

Zubaidah, S. (2016). Keterampilan abad ke-21: Keterampilan yang diajarkan melalui pembelajaran. Isu-Isu STrategis Pembelajaran MIPA Abad 21, $1-17$. 
